Г. Б. Кравченко, О. А. Красільнікова, В. П. Филимоненко Національний фармацевтичний університет, м. Харків

\title{
АНАЛІЗ РЕЗУЛЬТАТІВ ЛІЦЕНЗІЙНОГО ІСПИТУ “КРОК-1. ФАРМАЦІЯ” З ДИСЦИПЛІНИ “БІОЛОГІЧНА ХІМІЯ” СЕРЕД ІНОЗЕМНИХ СТУДЕНТІВ НАЦІОНАЛЬНОГО ФАРМАЦЕВТИЧНОГО УНІВЕРСИТЕТУ
}

\author{
H. B. Kravchenko, O. A. Krasilnikova, V. P. Fylymonenko \\ National University of Pharmacy, Kharkiv

\section{THE LICENSE EXAM “KROK 1. PHAPMACY” ON "BIOLOGICAL CHEMISTRY” FOR FOREIGN STUDENTS OF THE NATIONAL UNIVERSITY OF PHARMACY RESULTS EVALUATION}

\begin{abstract}
Мета роботи - аналіз результатів ліцензійного іспиту “Крок-1” з дисципліни “Біологічна хімія” серед іноземних студентів Національного фармацевтичного університету за останні 3 навчальні роки та порівняння отриманих результатів з результатами внутрішнього комп’ютерного тестування студентів, яке проводилося при підготовці студентів до “Кроку-1”.

Основна частина. Студенти були розподілені на 3 групи залежно від мови навчання. Дані виражали у вигляді $\mathrm{M} \pm \mathrm{m}$. Статистичну обробку даних проводили із застосуванням t критерію Стьюдента з використанням програми СТАТИСТИКА.

Було виявлено, що мовний фактор не чинить суттєвого впливу на результати тестування. Водночас поява нових, незнайомих “якірних” тестів суттєво знижує результат екзамену.

Висновок. Отримані результати мають важливе значення для подальшої підготовки іноземних студентів та вказують на необхідність впровадження нових методів навчання.

Ключові слова: ліцензійний іспит “Крок-1”; біологічна хімія; іноземні студенти; фармацевт; мовний фактор.

The aim of the study - to analyze the last 3 academic years results of licensed exam "Krok-1" discipline "Biological chemistry" for foreign students of the National University of Pharmacy and compare these results with the results of the internal department computer testing of students that was carried out in order to prepare students for passing "Krok-1".

The main body. The students were divided into 3 groups, depending on the language of instruction. The pre-test results and the results of the exam "Krok-1" were analyzed. Received data were expressed as $M \pm m$. The statistical significance of difference between groups was determined by Student's t test using STATISTICA program. It was found that the language factor has no significant effect on the exam results. At the same time, the introduction of new, unknown so called «anchor» questions significantly reduced exam results.

Conclusion. Current study is important for future training of foreign students and indicates the need for new teaching methods introduction.
\end{abstract}

Key words: licenced exam “Krok-1”; Biological Chemistry; foreign students; pharmacist; language factor.

Вступ. Тестовий ліцензійний іспит - це обов’язкова складова частина державної атестації для присвоєння кваліфікації провізора. Студенти, які навчаються за фахом “Фармація”, складають два окремих тестових іспити - “Крок-1” та “Крок-2” [1]. Перший екзамен “Крок-1. Фармація” складається з дисциплін природничо-наукового циклу, до якого, зокрема, входять тестові завдання з дисципліни “Біологічна хімія”, яку у Національному фармацевтичному університеті викладають на 3-му курсі.

(С) Г. Б. Кравченко, О. А. Красільнікова, В. П. Филимоненко
Результати ліцензійного іспиту “Крок-1” - це велике джерело важливої інформації, яке може бути використане викладачем з метою отримання додаткової інформації про ступінь засвоєння студентами викладеного матеріалу, а також з метою покращення процесу викладання біологічної хімії у НФаУ.

У НФаУ навчається велика кількість студентів $з$ різних країн світу, тому викладання проводиться різними мовами. Вітчизняні студенти навчаються українською мовою, іноземні студенти з англомовних країн (Гана, Кенія, Уганда, Нігерія, Ліван 
та інші) навчаються англійською мовою, іноземні студенти з країн СНД (Білорусь, Узбекистан, Туркменистан та інші), які вивчали російську мову у своїй країні, навчаються російською мовою, іноземні студенти з франкомовних країн (Марокко, Туніс, Алжир) та інших країн світу, де вони навчалися рідною мовою, зокрема арабською (Йорданія) або турецькою (Турція), після приїзду навчаються на підготовчому факультеті, де вивчають російську мову, якою вони попередньо не володіли. Щорічно результати ліцензійного іспиту “Крок” детально аналізуються професорсько-викладацьким колективом та керівництвом вишу, проте саме мовний аспект у викладанні та його вплив на результат тестування ще детально не проаналізовані [2].

Мета роботи - аналіз результатів ліцензійного іспиту “Крок-1” з дисципліни “Біологічна хімія” серед іноземних студентів з різною мовою навчання за останні 3 навчальні роки та порівняння отриманих результатів із результатами внутрішнього комп’ютерного тестування студентів, яке проводилося при підготовці студентів до “Кроку-1”.

Основна частина. Була проаналізована інформація щодо результатів ліцензійного та попереднього тестування 3 дисципліни "Біологічна хімія” іноземних студентів за три навчальні роки: 2013/2014 (“Крок-1” проводився 01.10.2014р.), 2014/2015 (“Крок-1” проводився 30.09.2015 р.) та 2015/2016 (“Крок-1” проводився 04.10.2016 р.). Студенти попередньо були розділені на 3 групи: 1 - іноземні студенти, які навчаються англійською мовою (Англ); 2 - іноземні студенти, які навчаються російською мовою, яку вивчали на підготовчому факультеті, після приїзду до України. До цього моменту російською мовою вони не володіли (ІФ); 3 - іноземні студенти, переважно з країн СНД, які вивчали російську мову на батьківщині та продовжують навчання цією мовою в університеті (СНД).
Використовували результати первинного проведення тестування ліцензійного іспиту “Крок-1”. Статистичну обробку даних проводили з використанням $t$ критерію Стьюдента за допомогою програми STATISTICA (StatSoftInc., США, версія 6.0) [3].

Тестування “Крок-1” проводиться за буклетом, до якого входять 200 тестів з різних дисциплін. Субтести з дисципліни “Біологічна хімія”, які входять до буклетів, поділяються на 2 групи. Це питання з відкритої бази та “якірні” питання з закритої бази, кількість яких кожен рік складає близько $25 \%$. Виключенням стали буклети для англомовних студентів у 2015/16 навчальному році, де кількість “якірних” тестів склала 40 \%. Цей факт, на наш погляд, $є$ основною причиною низького результату тестування англомовних студентів у 2015/16 році (табл. 1 ).

3 наведених даних видно, що у 2013/14 навчальному році більшість іноземних студентів успішно подолала “Крок-1”, при цьому результати, які студенти отримали за субтест “Біологічна хімія”, були дещо вищими за загальні результати. Достовірних відмінностей між групами, які навчалися різними мовами, виявлено не було. Слід зазначити, що з 2011-2012 навчального року на підставі аналізу результатів тестових іспитів були встановлені абсолютні величини критерію “склав” - 50,5 \% правильних відповідей, а починаючи з 2015/2016 навчального року, МОЗ України збільшило мінімальні критерії успішного складання ліцензійних інтегрованих іспитів до 60,5 \%. Результати тестування за 2014/15 навчальний рік показало, що більш успішно 60,5 \% відсотковий рубіж подолала група англомовних студентів, які навчалися англійською мовою (табл. 1).

Підготовка студентів до ліцензійного іспиту проходить поетапно, окрім усного опитування використовуються самостійна робота студентів, тесто-

Таблиця 1. Результати складання ліцензійного інтегрованого іспиту “KPOK-1. Фармація” студентами-

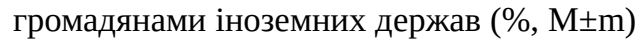

\begin{tabular}{|c|c|c|c|c|}
\hline \multirow{2}{*}{ Дата екзамену } & \multirow{2}{*}{ Показник } & \multicolumn{3}{|c|}{ Групи студентів } \\
\hline & & Англ & $\mathrm{I} \Phi$ & СНД \\
\hline \multirow{3}{*}{01.10 .2014} & Кількість студентів & 184 & 56 & 46 \\
\hline & Загальний тест & $58,7 \pm 7,9$ & $57,8 \pm 6,7$ & $51,8 \pm 7,4$ \\
\hline & Субтест “Біологічна хімія” & $60,7 \pm 7,4$ & $60,6 \pm 7,4$ & $53,8 \pm 8,6$ \\
\hline \multirow{3}{*}{30.09 .2015} & Кількість студентів & 63 & 76 & 57 \\
\hline & Загальний тест & $64,4 \pm 5,4$ & $52,3 \pm 7,2$ & $55,7 \pm 8,4$ \\
\hline & Субтест “Біологічна хімія” & $67,7 \pm 6,7$ & $54,9 \pm 6,4$ & $56,4 \pm 8,3$ \\
\hline \multirow{3}{*}{04.10 .2016} & Кількість студентів & 73 & 100 & 107 \\
\hline & Загальний тест & $57,7 \pm 6,3$ & $65,6 \pm 6,9$ & $69,4 \pm 7,9$ \\
\hline & Субтест “Біологічна хімія” & $54,6 \pm 7,5$ & $63,0 \pm 7,9$ & $69,9 \pm 7,4$ \\
\hline
\end{tabular}


ві завдання та інші види робіт [4]. Проте кінцеве оцінювання відбувається шляхом комп'ютерного тестування, в якому використовуються тести 3 відкритої бази. Всі групи іноземних студентів від- повідають на 100 тестів. Результати попереднього тестування наведені в таблиці 2.

Отримані результати свідчать про те, що немає суттєвої різниці між групами студентів, які навча-

Таблиця 2. Результати попереднього тестування з біологічної хімії при підготовці до іспиту “KPOK-1.

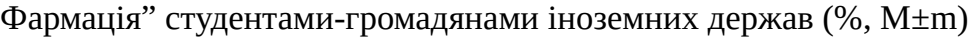

\begin{tabular}{|c|c|c|c|c|}
\hline \multirow{2}{*}{ Дата екзамену } & \multirow{2}{*}{ Показник } & \multicolumn{3}{|c|}{ Групи студентів } \\
\hline & & Англ & $\mathrm{I} \Phi$ & СНД \\
\hline \multirow[b]{2}{*}{2014} & Кількість студентів & 154 & 60 & 46 \\
\hline & $\begin{array}{l}\text { Результат тестування з біологічної } \\
\text { хімії }\end{array}$ & $71,6 \pm 4,6^{*}$ & $68,8 \pm 4,2 *$ & $70,4 \pm 4,2^{*}$ \\
\hline \multirow[b]{2}{*}{2015} & Кількість студентів & 53 & 84 & 59 \\
\hline & $\begin{array}{l}\text { Результат тестування з біологічної } \\
\text { хімії }\end{array}$ & $76,4 \pm 6,4^{*}$ & $71,8 \pm 5,2 *$ & $71,8 \pm 5,0 *$ \\
\hline \multirow[b]{2}{*}{2016} & Кількість студентів & 62 & 81 & 99 \\
\hline & $\begin{array}{l}\text { Результат тестування з біологічної } \\
\text { хімії }\end{array}$ & $71,9 \pm 5,8^{*}$ & $75,8 \pm 5,5^{*}$ & $74,7 \pm 4,5^{*}$ \\
\hline
\end{tabular}

Примітка. * - різниця достовірна (p $\leq 0,05)$ між результатом тестування з біологічної хімії та субтестом “Біологічна хімія” (табл. 1).

ються різними мовами. Проте результати попереднього тестування значно вищі, ніж результати “Кроку-1”.

Зниження результату при появі незнайомих для студентів питань, які не були у відомій базі, вказують на те, що студенти більш схильні заучувати питання та легко долають навіть високі критерії, однак поява “якірних" тестів провокує непорозуміння. При цьому сам змістовий контент для більшості студентів не повинен мати великої проблеми згідно з їхньою результативністю на поточних заняттях. На нашу думку, цю проблему можна вирішити впровадженням нових методів навчання. 3окрема, дуже добре зарекомендувало себе проблемно-орієнтоване навчання, яке набуває популярності у світі завдяки добрим результатам [2]. Такі методи дозволяють студентам бути більш гнучкими в сприйнятті матеріалу, поданого незвичним шляхом,

\section{Список літератури}

1. The problems of introduction of Bologna system in Ukrainian medical education and how they have been dealt with / I. Bulakh, V. Moskalenko, M. Mrouga, O. Volosovets // Матеріали конференції АMEE Conference, Відень, Австрія, 27.08-31.08.2011. - С. 437.

2. Аналіз результатів складання ліцензійного інтегрованого іспиту “Крок-1” та “Крок-2” іноземними студентами за 5 років / П. Т. Дацишин, С. В. Заїка, О. В. Федорченко, П. О. Стельмащук // Вісник Вінниць- стимулювати процеси не тільки запам'ятовування, але й незалежного мислення, що сприятиме у подальшому формуванню професійних якостей [1].

Висновки. Таким чином, на наш погляд, мовний фактор не чинить суттєвого впливу на результати тестування. Водночас поява нових, незнайомих “якірних” тестів суттєво знижує результат екзамену.

Отримані результати мають важливе значення для подальшої підготовки іноземних студентів та вказують на необхідність впровадження нових методів навчання.

У подальшому плануються пошук та розробка нових методів навчання і впровадження їх у процес підготовки іноземних студентів, які навчаються у Національному фармацевтичному університеті, 3 метою покращення засвоєння матеріалу в ході навчального процесу, а у перспективі - більш якісної підготовки магістрів фармації.

кого національного медичного університету. - 2016. T. 20, № 1, ч. 1. - С. 107-110.

3. Боровиков В. П. STATISTICA. Статистический анализ и обработка данных в среде Windows / В. П. Боровиков, И. П. Боровиков. - М. : Филинъ, 1995. - 608 с.

4. Багрій М. М. Поетапність підготовки до складання інтегрованого ліцензійного іспиту “Крок 1. Загальна лікарська підготовка” / М. М. Багрій // Галицький лікарський вісник. - 2013. - Т. 20, № 4. - С. 78-80. 
5. Problem-based learning in pharmaceutical education: a systematic review and meta-analysis / T. F. Galvao, M. T. Silva, C. S. Neiva [et al.] // Scientific World Journal. 2014. - V. 2014, Article ID 578382. - 7 p. Available at: http://dx.doi.org/10.1155/2014/578382.

\section{References}

1. Bulakh, I., Moskalenko, V., Mruha, M., \& Volosovets, O. (2011). The problems of introduction of Bologna system in Ukrainian medical education and how they have been dealt with. Materials of Conference: AMEE Conference, Videlles, Austria (27.08.-31.08.2011) (p. 437).

2. Datsyshyn, P.T., Zaika, S.V., Fedorchenko, O.V., \& Stelmashchuk, P.O. (2016). Analiz rezultativ skladannia litsenziinoho intehrovanoho ispytu «Krok-1» ta «Krok-2» inozemnymy studentamy za 5 rokiv [Licenced integrated test "Krok-1" and "Krok-2" results of foreign students for recent five years evaluation]. Visnyk Vinnytskoho natsionalnoho medychnoho universytetu - Bulletin of Vinnytsia National Medical University, 20(1), 107-110 [in Ukrainian].

3. Borovykov, V.P, \& Borovykov, I.P. (1995). STATISTICA Statisticheskiy analiz i obrabotka dannykh $v$ srede Windows [STATISTICA data analysis and processing in Windows environment]. M.: Filin [in Russian].
6. Lipton D. A. A review of legal decisions relevant to technical standards used in pharmacy school admissions / D. A. Lipton // American Journal of Pharmaceutical Education. - 2017. - Vol. 81 (2). - P. 37. Available at: http://www. ajpe.org/doi/full/10.5688/ajpe81237.

4. Bahrii, M.M. (2013). Poetapnist pidhotovky do skladannia intehrovanoho litsenziinoho ispytu «Krok 1. Zahalna likarska pidhotovka» [Phasing of preparation to the Integrated Licenced Test "Krok 1. General Medical Training”]. Halytskyi likarskyi visnyk - Galician Medical Journal, 20(4), 78-80 [in Ukrainian].

5. Galvao, T.F., Silva, M.T., Neiva, C.S., Ribeiro, L.M., \& Pereira, M.G. (2014). Problem-based learning in pharmaceutical education: a systematic review and metaanalysis. The Scientific World Journal. Retrieved from: http://dx.doi.org/10.1155/2014/578382.

6. Lipton, D.A. (2017). A Review of Legal Decisions Relevant to Technical Standards Used in Pharmacy School Admissions. American Journal of Pharmaceutical Education, 81(2), 37.

Електронна адреса для листування: krasilnikovaoksana16@gmail.com 